\title{
Burnout among Direct-Care Workers in Nursing Homes during the COVID-19 Pandemic in Spain: A Preventive and Educational Focus for Sustainable Workplaces
}

\author{
José Ángel Martínez-López ${ }^{1}$ (D) Cristina Lázaro-Pérez ${ }^{2}$ (D) and José Gómez-Galán ${ }^{3,4, *(D)}$ \\ 1 Department of Social Work and Social Services, University of Murcia, 30003 Murcia, Spain; jaml@um.es \\ 2 Department of Sociology, University of Murcia, 30100 Murcia, Spain; cristina.lazaro2@um.es \\ 3 Department of Education, University of Extremadura, 06006 Badajoz, Spain \\ 4 Cupey Campus, Ana G. Méndez University, San Juan, PR 00926, USA \\ * Correspondence: jogomez@uagm.edu; Tel.: +1-787-766-1717
}

check for

updates

Citation: Martínez-López, J.Á.; Lázaro-Pérez, C.; Gómez-Galán, J. Burnout among Direct-Care Workers in Nursing Homes during the COVID-19 Pandemic in Spain: A Preventive and Educational Focus for Sustainable Workplaces. Sustainability 2021, 13, 2782. https://doi.org/ $10.3390 /$ su13052782

Academic Editor: Francesco Caputo

Received: 12 January 2021

Accepted: 25 February 2021

Published: 4 March 2021

Publisher's Note: MDPI stays neutral with regard to jurisdictional claims in published maps and institutional affiliations.

Copyright: (C) 2021 by the authors Licensee MDPI, Basel, Switzerland. This article is an open access article distributed under the terms and conditions of the Creative Commons Attribution (CC BY) license (https:/ / creativecommons.org/licenses/by/ $4.0 /)$.

\begin{abstract}
Due to their continuous contact with pain and death, healthcare workers have one of the most stressful professions. Pain and death are more common in nursing homes. During the health crisis associated with COVID-19, these work centers have been characterized as spaces of high vulnerability to infection for the elderly, with a high mortality rate. This research aims to determine how the health crisis associated with COVID-19 has influenced healthcare professionals working in nursing homes for the elderly. Using a quantitative and cross-sectional method, the research was developed in residential centers in the Region of Murcia (Spain) during the second wave of the pandemic. A survey design based mainly on the Maslach Burnout Inventory (MBI) was employed. MBI measures three subscales: emotional burnout, depersonalization, and self-fulfillment. The results show that $6.4 \%$ of the respondents were burned out, $53.8 \%$ of the participants were emotionally exhausted, $35.1 \%$ were found to suffer from depersonalization, and in the case of personal development, the respondents showed a low level of $15.6 \%$. This study shows the need to consider the establishment, in the academic environment, of training programs for health professionals related to coping with, managing, and identifying stress, especially in adverse circumstances. Similarly, in the professional field, it is necessary to develop strategies to prevent stress and anxiety in the workplace. The development of training programs for this purpose is essential for achieving a sustainable work context.
\end{abstract}

Keywords: COVID-19; health professionals; burnout; Spain; nursing homes; senior centers; prevention; training programs; sustainable work environments

\section{Introduction}

The appearance at the end of 2019 of the coronavirus (SAR-CoV-2) in Wuhan (China), which provoked the subsequent COVID-19 pandemic, necessitated a reorganization of all social, medical, political, cultural, and individual scenarios all over the world. Since 30 January 2020, when the World Health Organization called it a "public health emergency of international concern" [1], terror and panic gripped the world's population, mainly because of the rapid spread and virulence of the virus, especially among the most vulnerable healthcare population: the sick and the elderly. This means that many people were the hardest hit by COVID-19 in the first wave.

Recent studies [2-6] have shown that working in the COVID-19 pandemic is having a significant psychosocial impact on health professionals, especially those who work in more fragile contexts, with long working hours, without adequate Personal Protection Equipment, etc.

The main psychosocial risks are stress, burnout, and violence, which affect individuals physiologically, emotionally, cognitively, socially, or physically and can induce absenteeism and abandonment of work [7]. These risks guide the investigation of this social 
phenomenon, considering the social, ethical, political, and management implications that currently exist as a consequence of COVID-19.

In this connection, we found that Spain is becoming a constantly aging country, with $30 \%$ of people over 65 , who are physically, psychologically, and/or functionally dependent on others $[8,9]$. This means that there is a great need for help, given the needs of the residents themselves [10]. According to the latest statistics from the Continuous Census of the National Institute of Statistics [11], the elderly in Spain number 9,217,464 (65 years and over), which represents $19.4 \%$ of the total population $(47,431,256$ people). Moreover, according to the figures for residential centers in Spain, there are 3844 private and 1573 public ones, which gives us a figure of 5417 homes for the elderly in the whole of Spain, with 372,985 beds (271,696 private and 101,289 public), which are occupied by $70.4 \%$ of women and $81.8 \%$ of men over 80 years of age [12].

The age range of greatest vulnerability to COVID-19 has been from 70 years of age [9], with an observed fatality rate of 19\% in May 2020, 88,094 reported cases, and 16,559 reported deaths, according to official figures [13]. However, the Daily Mortality Monitoring System [13] showed that 37,227 deaths were in people over 74 years of age, representing $77.9 \%$ of excess deaths in the period. In November, this figure was 18,915, representing 19.9\%.

In December 2020, the number of people who died with COVID-19 or similar symptoms and were living in nursing homes stood at 23,787 , i.e., about $51 \%$ of the deaths officially reported by the Ministry of Health of people with coronavirus [14]. The serious risk factors for the residents have been old age and comorbidities, the most frequent being high blood pressure, kidney, lung, and heart diseases, obesity, diabetes mellitus, and cancer $[15,16]$. Another factor favoring transmission has been contact with other residents and staff who have cared for them, as well as the closed environment in which they were found [17].

It is precisely these workers who, in their capacity as healthcare providers and caregivers, have had to face a tough situation, with a double objective: to care for their residents and to ensure that neither they nor their residents are infected by the virus. The situation of the residences in Spain during the first wave of the COVID-19 was developing amidst political tension regarding the protocols to be followed in the case of coronavirus infection, especially during the first two weeks of the state of alarm decree and the subsequent confinement of the population on 14 March 2020 [18].

The residential care service is detailed in Law 39/2006 on the Promotion of Personal Autonomy and Care for Dependent Persons (Promoción de la Autonomía Personal y Atención a las Personas en Situación de Dependencia) [19]. This service enjoys the highest level of concession [20,21], although the economic benefits for care in the family environment and support for non-professional caregivers are the most frequently granted among the set of economic benefits and services introduced since the system was implemented [19,22-24].

The professional care of the elderly carried out by health personnel takes the form of help in the Basic Activities of Daily Life (BADL). Therefore, the conditions in which they carry out their professional work must be appropriate; otherwise, it could involve risks that would affect not only their careers, but also the residents. The continuous contact with the residents, the intensity and duration of this contact, the excessive workload, the work environment, and the organization associated with the professional care of the elderly are factors that can increase the predisposition to psychosocial risks, such as burnout or stress [7].

This situation is compounded in the context of the pandemic, during which, and especially during the first wave, the lack of action protocols, equipment, and individual protection teams could have compromised the precipitating factors of psychosocial risk. This is because a good part of the residents contracted the virus, and others died before their eyes, without any way of avoiding it. In addition, there is the consequent risk of the caregivers getting sick and exporting the virus to their own families outside the residences. Some failures that stood out during the first wave could have been largely avoided during 
the second, but infections and deaths have continued to occur in smaller numbers, although they remain high.

\section{Background}

The healthcare profession, which includes residential care for the elderly, is the profession that generates the most work stress or burnout due to healthcare professionals' continuous contact with pain and suffering $[25,26]$. However, their performance of monotonous tasks, the excessive workload, the frequency and amount of social time, and deficient interpersonal relationships, together with the organizational climate and the characteristics of the job, are also predictive variables [27].

Burnout syndrome precipitates certain disorders that force the affected person to temporarily stop working [28], such as headaches or backaches, sexual and central nervous system dysfunctions, muscular tension, generalized musculoskeletal pain, and various cardiovascular and gastrointestinal problems [29].

Previous studies on burnout in health professionals have been able to relate certain symptoms of different disorders, such as mood, anxiety, and depression [30-33], affecting not only the workplace, but also the social and family environment [34,35].

In the geriatric context, there has been a lot of research on stress and burnout, since long-term care for dependent elderly people can negatively affect people's well-being and health [36], since it is a physically and emotionally demanding occupation.

Burnout is defined as a "prolonged response to chronic personal and relational stressors at work, determined by the dimensions known as burnout, depersonalization, and professional cynicism and inefficiency" [34,37].

Dr. Maslach and Dr. Jackson [37] spoke of a process of chronic contact stress, which was measured through an inventory developed by the aforementioned authors and used in the present study. It is composed of the following dimensions. Firstly, emotional fatigue, which is determined by the gradual loss of energy and exhaustion; that is, the experience of being emotionally exhausted by the demands of the work. Secondly, depersonalization, which indicates the degree to which each person recognizes attitudes and is marked by negative attitudes that result in a distancing from problems and even blaming the patients themselves for the problems suffered by the professional. Thirdly, lack of personal fulfillment, which is characterized by negative responses to oneself and one's work, with pseudo-depressive manifestations, tendencies to run away, physical and psychic exhaustion, and dehumanization. Thus, this third subscale evaluates feelings of self-efficiency and self-fulfillment at work.

Considering the context of the pandemic, and the problems associated with the work of nursing home healthcare providers, it is necessary to know the effects that nursing home workers may be experiencing. Thus, if the data are alarming, similar situations could be prevented in the future in the context of other possible waves of COVID-19 involving a high number of infected and dead people. Health professionals' levels of personal exhaustion, depersonalization, and self-fulfillment during the first wave exploded [20], which means that they suffered an increase in burnout syndrome.

The psychological health risk in these professionals must be faced not only when it occurs, but also from a preventive perspective, from which initial and continuous training programs are fundamental. At present, sustainable working environments must be developed that provide safety and well-being to workers in multiple dimensions, while enhancing their productivity even in extreme situations, such as those described, which must be contemplated in connection with these prevention strategies.

There has been little scientific literature related to the experiential processes of residential care workers, such as the development of burnout, both in Spain and in other countries, so researching this may help to improve the quality not only of the professionals themselves, but also of the care. If there is one good thing about the times of epidemics and pandemics, it is that they bring to the table the functioning of all categories of the population, showing their strengths and weaknesses at the structural and organizational, 
institutional, and even personal levels. Knowing this will help to improve our ability to face new events more efficiently.

\section{Materials and Methods}

\subsection{Objectives}

The increase in care pressure in residential centers due to the high mortality rate of residents in Spain may have had repercussions in the personal sphere of professionals and in their work dynamics, according to the dimensions of Maslach and Jackson [37]. In this context, two objectives are raised. The first is to determine the general burnout level and the set of subscales of the Maslach Burnout Inventory (MBI) (O1). The second is to determine the predictive variables that influence the burnout phenomenon in these professionals $(\mathrm{O} 2)$.

The hypothesis guiding the present investigation is that because of the high mortality in residential centers for the elderly since the beginning of the health crisis, and since this population group is one of the most vulnerable in the COVID-19 pandemic, burnout may be endemic in their workers due to occupational stress and prolonged contact with death.

\subsection{Instrument}

The instrument selected to achieve the stated objectives was the MBI, developed by Maslach and Jackson [37], adapted by Gil-Monte [38], and applied to professionals working in residential homes for the elderly. This scale allows a general index of burnout and a set of subscales that compose it to be obtained, including Emotional Exhaustion (EE), Depersonalization (DP), and Personal Accomplishment (PA). The MBI is composed of 22 items through a Likert scale, whose response options range from 0 to 6 . The EE scale is composed of seven items, the DP is composed of five, and the PA is composed of eight. In the case of EE, low levels are values between 0-18, medium levels are between 19-26, and high levels are between 27-54. Regarding DP, low levels are between 0-5, medium levels are between 6-9, and high levels oscillate between 10-30. Concerning PA, low levels comprise the values of $0-33$, medium levels $34-39$, and high levels $40-56$. To interpret the existence of burnout, a triple condition must be met: a high level in EE and DP and a low level in PA.

Concerning the Cronbach's Alpha means, $\alpha$ (or the original version [37] of the alpha coefficient) was obtained for the EE dimension (0.89), for the DP dimension (0.77), and the PA dimension (0.74). In our version adapted to Spanish [38], a Cronbach's Alpha mean of 0.85 was obtained for the EE dimension, 0.58 for the DP dimension, and 0.71 for the PA dimension.

In addition to this burnout block, the questionnaire was made up of (a) a block of socio-demographic issues, and (b) subjective perceptions about their working conditions and the need for psychological and psychiatric treatment.

\subsection{Sample}

Concerning the participants in the research, the number of residential care workers was $n=296$, and the main characteristics are shown in Table 1. Most of the participants were female, representing $86.1 \%$ of the total, with the percentage of men remaining at only $13.9 \%$. This reflects the feminization of care, both in formal and informal spaces. In terms of age, the majority group was up to 30 years old and between 41-50 years old, registering values of $31.8 \%$ and $28.7 \%$, respectively, together adding up to $60.5 \%$.

Concerning the professional category, Nurse Assistants stand out, being $88.8 \%$ of all participants. It should be noted that, in the case of Spain, Nurse Assistants are not an extension of Nurses, since they are different professional categories. While a Nurse requires a university degree within the European Higher Education Area, the same is not true for Nurse Assistants, whose required degree is not a university degree and who perform functions related to personal hygiene, meal support, room preparation, etc. In residential centers, most of the staff are Nurse Assistants and Nurses, who administer medication, 
monitor vital signs, follow the guidelines established by the physician, etc. Within the healthcare setting, physicians have a residual representativeness, given that when there is an important medical problem requiring hospital care, these patients are transferred to these centers. Therefore, the sample includes more Nurse Assistants.

Table 1. Participants in the research.

\begin{tabular}{cc}
\hline Participants & $\%$ \\
\hline Sex & \\
Woman & 86.1 \\
Man & 13.9 \\
Age & \\
$31-40$ & 31.8 \\
$41-50$ & 21.3 \\
$51-60$ & 28.7 \\
$>60$ & 17.2 \\
Work & 1.0 \\
Nurse & \\
Nurse Assistant & 9.2 \\
Other & 88.8 \\
Type of Nursing Home & 2.0 \\
Public & \\
Private & 26.7 \\
Yes & 73.3 \\
No & 18.4 \\
$n=296$ & 81.6 \\
\hline
\end{tabular}

Concerning the type of center, $26.7 \%$ work in public residences and $73.3 \%$ in residences subsidized by the public administration, where there is financing from the public administration in the management of the residential space. No residential center took part that was entirely privately funded, which has a residual character in the overall care of dependent persons in Spain. Finally, of the group of participants, only $18.4 \%$ were experiencing an active COVID-19 outbreak in their residential center at the time of completing the questionnaire.

\subsection{Variables}

The dependent variable of this research corresponds to the burnout levels, both in the case of the general index and each one of its subscales: EE, DP, and PA.

The independent variables used were: (a) sex, (b) age, (c) professional category, (d) ownership of the center, (e) Need for Psychological/Psychiatric Support (NPPS), (f) Psychological/Psychiatric Support Should be Offered from Workplaces (PPSS), (g) Psychological/Psychiatric Support may be Needed (PPSN), and (h) Active COVID-19 outbreak in your workplace (ACOW).

While other questions could have been raised, all independent variables are related to the MBI and provide information on: (a) the environment in which the healthcare professionals work and their feeling of belonging to their institution and (b) their feelings and perception of their own and collective mental health as a consequence of the pandemic.

\subsection{Procedure}

The field research was conducted from 9 November to 27 November 2020, during the peak of the second wave of the COVID-19 in Spain. The study focused on a single territory (in this case, the Region of Murcia), on the one hand, given the difficulties of implementing it in the whole of Spain, and on the other, the need to obtain data on the implications of emotional stress and anxiety in workers in residential centers at such a crucial time of the pandemic. This research had the benefit of collaborating with the Murcian Institute of 
Social Action (Instituto Murciano de Acción Social), which administered the questionnaire to its workers.

The research work met all the ethical requirements in the scientific field. All the participants $(n=296)$ gave their informed consent, following the Declaration of Helsinki. While in Spain, no official approval of the ethical committees of the universities for studies of this nature, i.e., descriptive ones (it is required only in the experimental ones) is needed, in this study, we applied all the Codes of Good Practice of Research in Human Beings of the universities. The work was registered and signed by the research team, which includes the authors of the work, with the code $n^{\circ}$ REPRIN-PEM-21, abiding the rules of all Ethics Committees.

The following phases were followed in the process of data exploitation and analysis using the SPSS v.24 program (IBM). Initially, a frequency analysis was performed to determine the existence of the general level of burnout and each one of its subscales. Then, to obtain information about the variables linked to this phenomenon, a cross-table analysis was performed, taking into consideration a chi-square $p \leq 0.05$. Finally, to determine the predictive variables of the phenomenon, binary logistic regressions were performed, taking as variables the existence of the general burnout level and the reference level of each subscale to determine the existence of burnout.

The variables used in the binary logistic regression are shown in the following table (Table 2).

Table 2. Variables used in the binary logistic regression.

\begin{tabular}{c} 
Sex \\
Ref. Man \\
$(1)$ Woman \\
Age (Continue) \\
Ref. $>60$ \\
$(1) \leq 30$ \\
$(2) 31-40$ \\
$(3) 41-50$ \\
$(4) 51-60$ \\
Work \\
Ref. Other \\
(1) Nurse \\
(2) Nurse Assistant \\
Type of Nursing Home \\
Ref. Public \\
(1) Private \\
Ref. No \\
Yes \\
Need for Psychological/Psychiatric Support (NPPS) \\
Ref. No \\
Yes \\
Psychological/Psychiatric Support may be Needed (PPSN) \\
Ref. No \\
Yes \\
Ref. No \\
Yes \\
\hline
\end{tabular}

\section{Results}

First, it can be stated that the burnout levels were not excessively high, from the point of view of the set of subscales and concerning the general burnout level. Second, the EE subscale recorded the highest values, reaching $53.8 \%$ of the participants. Concerning DP, the high level of the subscale showed values lower than that of EE, standing at $35.1 \%$, which is similar to the low-level values of EE, which stood at $35.8 \%$. For the subscale PA, 
the low level (reference value for measuring burnout) reached 15.6\%. Finally, concerning Burnout, $6.4 \%$ of workers who showed high levels of EE and DP and low levels of PA suffered from it. Regarding NPPS, $21.6 \%$ stated that they needed it at present; however, $41.0 \%$ stated PPSN. One fact stands out, namely, that $90.4 \%$ stated PPSS, which is a high figure (Table 3).

Table 3. Descriptive results.

\begin{tabular}{cc}
\hline Sub Emotional Exhaustion (EE) & \\
Low & 28.7 \\
Medium & 18.3 \\
High & 53.0 \\
Sub De-Personalization (DP) & \\
Low & 35.8 \\
Medium & 29.1 \\
High & 35.1 \\
Sub Personal Accomplishment (PA) & \\
Low & 15.6 \\
Medium & 28.0 \\
High \\
Total MBI \\
Yes & 56.4 \\
No & 6.4 \\
Yes & 93.6 \\
No & 21.6 \\
Need for Psychological/Pschiatric Support (NPPS) & 87.4 \\
Yes & 90.4 \\
No & 9.6 \\
Psychological/Psychiatric Support Should be Offered from Workplaces (PPSS) & 41.0 \\
Yes & 59.0 \\
\hline No & \\
\hline
\end{tabular}

Then, the technique of crossed tables was applied, using each subscale as dependent variables: EE, DP, and PA, with a chi-square significance level $\leq 0.05$ (See Appendix A). The most outstanding results are the following. First, no significant differences are observed in sex in the set of subscales. We did observe some differences in age, especially in the younger age group in PA. This subscale obtained the highest values among people up to 30 years of age and the lowest values in older people. Therefore, the lack of PA decreases as age increases in residential professionals.

Concerning the professional category, there are also differences. The highest levels of EE and DP are found among Nurse Assistants, while Nurses showed the highest PA. The participation of other professional categories (including Physicians) was irrelevant in the sample.

In terms of residential center ownership (public/private), among public residential staff, we found high values of PA (31.8\%), followed closely by EE (29.0\%). Concerning staff in private residences, the DP scale was over-represented (75.0\%), followed by EE (71.0\%).

Significant data are obtained concerning NPPS; although they were very similar between subscales, we obtained significance, and the need for psychological treatment was determined by the values obtained in the set of subscales. Thus, it was possible to establish an association between the levels of burnout and the need for this type of treatment. Moreover, there is a significant association (in terms of chi-square) between the PPSN variable and EE. In this way, the EE situation can determine PPSN.

As for PPSS, the values were high in the set of subscales, but they stood out especially in EE and, again, had a relevant level of significance in terms of chi-square. Finally, concerning ACOW, it had similar values in the set of subscales (around $20 \%$ ), so the existence of an active outbreak of COVID-19 in residences did not predispose people to a high level of burnout. 
Subsequently, the technique of binary logistic regression was applied to all the subscales of the MBI and to the burnout index. Only adequately adjusted, robust, and reliable models were obtained for EE and the burnout index. Each of the models is developed below.

The binary logistic regression of EE presented a statistically significant model $\left(\mathrm{X}^{2}=50.600, p<0.001\right)$. The model explained $22.5 \%$ (Nagelkerke's $\left.\mathrm{R}^{2}\right)$ of the variance and correctly classified $67.5 \%$ of the cases. The Hosmer-Lemeshow test showed that there were no significant differences between the observed and predicted results in the model, with a $p=0.998$.

The variables included in the equation were: (a) PPSN, (b) PPSS, and (c) Type of nursing home (Private). Regarding the PPSN, it presented an Odds Ratio (OR) $=4.905, \mathrm{CI}$ $95 \%$ [2.759-8.722], and $p<0.001$. The subjective perception of needing psychological or psychiatric treatment $=$ increased the chances of these workers (up to almost five times higher) suffering in the EE. PPSS showed an OR $=3.436$ (CI 95\% [1.223-9.655], $p=0.019$ ). In this way, the chance of suffering from burnout of those who consider that attention should be paid to their work centers in the context of COVID-19 increased in the PPSS subgroup by almost 3.5 times. Concerning the type of center, workers in subsidized centers showed an $\mathrm{OR}=1.863$ (CI 95\% [1.021-3.400], $p=0.043$ ). Therefore, when working in a private residence, the staff suffered up to two times more EE.

If the Burnout index was taken into consideration, we observed that the binary logistic regression presented a statistically significant model $\left(\mathrm{X}^{2}=10.091, p<0.017\right)$. The model explained $4.9 \%$ (Nagelkerke's $\mathrm{R}^{2}$ ) of the variance of moderate-high consumption and correctly classified $93.4 \%$ of the cases. The Hosmer-Lemeshow test showed that there were no significant differences between the results observed and those predicted in the model, with a $p=0.424$. While the model explains a reduced percentage based on Nagelkerke's $\mathrm{R}^{2}$, it should be noted that the percentage of workers suffering from burnout is very low, at $6.4 \%$; however, given that the model is properly adjusted, it is interesting to consider these results.

The variables included in the equation are: (a) Work (Nurses) and (b) NPPS. Regarding Nurses, an OR $=25.954$ is obtained (CI 95\% [1.478-455.647], $p=0.026$ ). Therefore, being a nurse increased the risk of suffering burnout by up to almost 26 times, with respect to the reference category (others). The NPPS subgroup presented an OR $=3.835$ (CI 95\% [1.392-10.564], $p=0.009$ ). Thus, the subjective perception of needing psychological treatment increased the chances of suffering burnout by almost four times (Table 4).

Table 4. Summary of binary logistic regression models.

\begin{tabular}{cccccc}
\hline & \multirow{2}{*}{ B } & Sig. & Exp(B) & \multicolumn{2}{c}{$\mathbf{9 5 \% \text { C.I. Exp(B) }}$} \\
\cline { 5 - 6 } & & & & Lower & Superior \\
\hline $\begin{array}{c}\text { Sub Emotional Exhaustion } \\
\text { Type of Nursing Home (Private) }\end{array}$ & 0.622 & 0.043 & 1.863 & 1.021 & 3.400 \\
PPSN & 1.590 & 0.000 & 4.905 & 2.759 & 8.722 \\
PPSS & 1.234 & 0.019 & 3.436 & 1.223 & 9.655 \\
Constant & -2.006 & 0.000 & 0.134 & & \\
Burnout total & & & & & \\
Work: Nurse & 3.256 & 0.026 & 25.954 & 1.478 & 455.647 \\
$\quad$ Constant & 1.344 & 0.009 & 3.835 & 1.392 & 10.564 \\
Currently Needing Treatment (NPPS) & -3.256 & 0.000 & 0.039 & & \\
\hline eb = Exp (B). Sig (Significance level) $=0.05 ; \operatorname{Sig} p<0.001$. & & & &
\end{tabular}

\section{Discussion}

Concerning the burnout rate, it is surprising that only $6.4 \%$ of the workers registered it, despite the collapse of these centers, the high mortality rate of the residents, and the media pressure on the public management of the residential centers. These figures are much lower than those found in other studies conducted on the pandemic in Spain because 
of COVID-19 on health workers or the Security Forces, which are essential sectors during the pandemic [20,39].

A characteristic of care is the fact that, if we make an approximation to the subscales, we observe a significant increase in the records of the three subscales that make up the MBI in comparison with other studies also carried out in this territory [40]. Likewise, the highest percentage of the subscales is concentrated in workers who suffer from EE, which stands at $53.8 \%$. As for DP, $35.1 \%$ is concentrated in professionals working in homes. However, the lowest levels are found among people with a lack of PA, which only reaches $15.6 \%$ of workers. Here, it is important to note that it mainly affects younger people up to 30 years of age, as noted in previous studies [41]. Thus, we consider that the lack of personal fulfillment decreases as age increases in residential care professionals. However, in other previous studies, no conclusive results were found for the age variable [38,42-44].

Concerning the rest of the variables introduced in the research, the NPPS only reaches $21.6 \%$, while the subjective perception of PPSN doubles to $41.1 \%$. However, it reaches $90.4 \%$ of PPSS. The paradox is that, although NPPS is not perceived at the moment at an individual level, nor is there a disproportionate increase in the short term, the work climate, social problems, and the collective sphere of work affect the perception of the need for psychological or psychiatric attention to the workers affected by the COVID-19 pandemic.

A major controversy, introduced into the public debate as a result of the high mortality rate, has been the assumption that the public administration should take over residential facilities, especially after the process of medicalizing these facilities. However, significant differences can only be observed in terms of PA, and it is precisely in the workers in public residences where higher levels are recorded. Among the personnel of public residences, considering all the subscales of the MBI, the lack of PA (31.8\%) stands out above EE and DP.

Regarding the subjective variables analyzed through the cross-tables, they are closely connected with elevated levels of EE, which are especially disposed to NPPS, PPSN, and PPSS. Thus, a high EE can significantly influence these aspects. No differences are observed between the ACOW and the records obtained in the different burnout subscales. Thus, ACOW does not cause increased levels of stress and/or anxiety, partly because the risk is very high and could be found in any workplace, despite not being detected. This assumption is unlike that employed in other studies, which relate stress to active cases [20].

While the applied binary logistic regressions only obtained significant data in EE and Burnout, the results to be considered are shown. As for EE, workers who consider PPSN and PPSS are at a greater risk. This finding is unlike that presented in other studies, which show that this subscale is determined by the professional category, mainly affecting those who have more responsibility for medical treatment [20,45]. Additionally, in this case, there are differences between workers in public nursing homes and those who work in private nursing homes, showing that the former have a greater risk of suffering from EE.

As for burnout, high values are obtained for nurses, whose levels are up to 26 times higher than the reference value. If we add to this the fact that the highest levels of DP are found in young people and in nurses, the data seem to show that young nurses suffer from a high PA, which, together with the other subscales, leads to burnout. It should also be considered that young nurses represent the highest percentage of professionals that are permanently present in residential centers, which is not the case for center directors or physicians. This responsibility can act as a stressor for young nurses who have developed their professional activity in this context, even though it is one of the fastest-growing professions [46]. Similar results have been found in other research on health personnel, where the highest burnout was seen in older professionals [20]. Moreover, the subjective perception of NPPS is also a predictive variable for suffering burnout. In this sense, some authors obtained results in both directions $[47,48]$. For example, some authors found that the less professional seniority workers have, the more likely they are to develop the syndrome, while other authors obtained a negative relationship between this variable and burnout $[42,49]$. 
One characteristic of care is the feminization of the personnel working in these centers [50-53], either in the informal space of the private sphere or, in this case, in residential care services.

In this context, therefore, it is more urgent than ever to develop specialized training programs, both initial and continuing, for professionals in this field [54-58]. In particular, one should focus on exceptional situations that, as in the case of the pandemic, may increase the psychological impact that workers may suffer [59-63]. Today, the concept of sustainable work environments must be analyzed in the academic world, in initial training, and in professional training proposals [64-66]. In the broad framework that this implies, seeking to reconcile work and family life, gender equality, flexibility, team building, welfare, workspaces, etc. [65], we determine measures for the care and prevention of health problems, among which psychological problems represent a great risk for healthcare workers [67-69].

In the context of all the current measures that seek the productivity and welfare of workers and that, in recent years, have been directed to improvements and progress towards a more collaboration, flexibility, justice, etc. [65], as well as more sustainability in the short term, exceptional events such as epidemics, natural disasters, economic crises, etc., must also be considered, as such events exacerbate the risk factors faced by workers. Educational strategies are fundamental [70,71], especially from a holistic perspective [72,73]. They are the basis of prevention, and it is, therefore, urgent that they are integrated, as has been pointed out, into the initial and ongoing processes of these professionals. Only in this context can true sustainability be achieved.

\section{Conclusions}

The results of the research show low levels of burnout; however, they show excessively high levels of Emotional Exhaustion. This may be a risk factor in the development of mental disorders in the medium and long term in professionals working in residential centers. Considering the results, it is necessary to establish, both in the academic environment and in the management of nursing homes, training related to coping, managing, and identifying stress through health sciences grades. Likewise, in the professional field, developing strategies to prevent stress and anxiety at work, such as promoting improved interpersonal relationships, is crucial to maintaining good personal health and a productive and sustainable work environment.

The prevention of stress must be adapted to the characteristics of the job, considering the optimization of the job, social support, and compensation for efforts that workers make [51]. In this sense, the creation, development, and consequent application of training programs are essential. It is not in vain that research, training, and education in health matters are supported by the Framework Directive on Health and Safety at Work (Directive 89/391 EEC) of the European Union.

Concerning the limitations of the study, we experienced difficulty in accessing the respondents, because after an intense period of living in the context of the first wave and then in the second wave, with more infections and deaths than the first, the predisposition to answer a questionnaire was low. Moreover, including a qualitative perspective would allow us to determine how burnout influences both the work dynamics and the individual sphere of the participants.

Another important limitation is the type of study, which is cross-sectional. In the future, it would be interesting to deepen this object of study by including the participants themselves to see how burnout levels develop from a longitudinal perspective.

Finally, it should be added that, in the future, the sample should be enlarged to include a greater representation of the professional groups of nursing homes.

Author Contributions: Conceptualization, J.Á.M.-L., C.L.-P. and J.G.-G.; methodology, J.Á.M.-L., C.L.-P. and J.G.-G.; validation, J.Á.M.-L., C.L.-P. and J.G.-G.; formal analysis, J.Á.M.-L., C.L.-P. and J.G.-G.; investigation, J.Á.M.-L., C.L.-P. and J.G.-G.; data curation, J.Á.M.-L., C.L.-P. and J.G.-G.; writing-original draft preparation, J.Á.M.-L., C.L.-P. and J.G.-G.; writing-review and editing, J.G.- 
G.; supervision, J.Á.M.-L., C.L.-P. and J.G.-G.; project administration, J.Á.M.-L., C.L.-P. and J.G.-G. All authors have read and agreed to the published version of the manuscript.

Funding: This research received no external funding.

Institutional Review Board Statement: The study was conducted according to the guidelines of the Declaration of Helsinki.

Informed Consent Statement: Informed consent was obtained from all subjects involved in the study.

Data Availability Statement: Data available on request due to privacy and ethical restrictions. The primary data are contained within the article.

Acknowledgments: We thank the General Director of Elderly People (Director General de Personas Mayores) of the Murcian Institute of Social Action (Instituto Murciano de Acción Social) for the valuable help in the implementation of this research.

Conflicts of Interest: The authors declare no conflict of interest.

\section{Appendix A}

Table A1. Results of the crossed tables, according to the MBI subscale.

\begin{tabular}{|c|c|c|c|}
\hline Variables & EE & DP & PA \\
\hline \multicolumn{4}{|l|}{ Sex } \\
\hline Woman & 84.5 & 87.3 & 84.1 \\
\hline Man & 15.5 & 12.7 & 15.9 \\
\hline \multicolumn{4}{|l|}{ Age } \\
\hline Over 30 & 30.6 & 37.5 & 39.1 \\
\hline $31-40$ & 21.0 & 25.0 & 23.9 \\
\hline $41-50$ & 30.6 & 22.1 & 28.3 \\
\hline $51-60$ & 17.2 & 15.4 & 8.7 \\
\hline$>60$ & 0.6 & 0 & 0 \\
\hline \multicolumn{4}{|l|}{ Work } \\
\hline Nurse & 10.3 & 6.9 & 13.3 \\
\hline Nurse Assistant & 89.1 & 92.1 & 82.2 \\
\hline Other & 0.6 & 1 & 4.4 \\
\hline \multicolumn{4}{|l|}{ Type of Nursing Home } \\
\hline Public & 29.0 & 25.0 & 31.8 \\
\hline Private & 71.0 & 75.0 & 68.2 \\
\hline Need for Psychological/Psychiatric Support & * & * & * \\
\hline Yes & 32.5 & 31.1 & 35.6 \\
\hline No & 67.5 & 68.9 & 64.4 \\
\hline Psychological/Psychiatric Support may be Needed & * & & \\
\hline Yes & 58.3 & 46.2 & 52.3 \\
\hline No & 41.7 & 53.8 & 47.7 \\
\hline To Offer Attention from Work Centers & * & & \\
\hline Yes & 96.8 & 89.4 & 93.3 \\
\hline No & 3.2 & 10.6 & 6.7 \\
\hline
\end{tabular}


Table A1. Cont.

\begin{tabular}{cccc}
\hline Variables & EE & DP & PA \\
\hline Active Outbreak of COVID-19 & & & \\
\hline Yes & 22.4 & 18.4 & 22.2 \\
\hline No & 77.3 & 81.6 & 77.8 \\
\hline$n=296$ & $157(53 \%)$ & $104(35.1 \%)$ & $46(15.5 \%)$ \\
\hline & &
\end{tabular}

\section{References}

1. World Health Organization (WHO). Statement on the Second Meeting of the International Health Regulations (2005) Emergency Committee Regarding the Outbreak of Novel Coronavirus (2019-nCoV). 2020. Available online: https://cutt.ly/bjcpNKw (accessed on 19 October 2020).

2. Martínez-López, J.Á.; Lázaro-Pérez, C.; Gómez-Galán, J.; Fernández-Martínez, M.M. Psychological Impact of COVID-19 Emergency on Health Professionals: Burnout Incidence at the Most Critical Period in Spain. J. Clin. Med. 2020, 9, 3029.

3. Aiello, A.; Khayeri, M.Y.; Raja, S.; Peladeau, N.; Romano, D.; Leszcz, M.; Maunder, R.G.; Rose, M.; Adam, M.A.; Pain, C.; et al. Resilience training for hospital workers in anticipation of an influenza pandemic. J. Contin. Educ. Health Prof. 2011, 31, 15-20. [CrossRef] [PubMed]

4. Liu, Z.; Han, B.; Jiang, R.; Huang, Y.; Ma, C.; Wen, J.; Zhang, T.; Wang, Y.; Chen, H.; Ma, Y. Mental health status of physicians and nurses during COVID-19 epidemic in China. Lancet 2020. [CrossRef]

5. Maunder, R.G.; Lancee, W.J.; Mae, R.; Vincent, L.; Peladeau, N.; Beduz, M.A.; Hunter, J.J.; Leszcz, M. Computer-assisted resilience training to prepare healthcare workers for pandemic influenza: A randomized trial of the optimal dose of training. BMC Health Serv. Res. 2010, 10, 72. [CrossRef] [PubMed]

6. Xiao, H.; Zhang, Y.; Kong, D.; Li, S.; Yang, N. The effects of social support on sleep quality of medical staff treating patients with coronavirus disease 2019 (COVID-19) in January and February 2020 in China. Int. Med. J. Exp. Clin. Res. 2020, 26, e923549.

7. Instituto Nacional de Seguridad y Salud en el Trabajo (INSST), O.A., M.P. Guía para la Gestión de los Riesgos Psicosociales en la Actividad de Cuidado de Personas Mayores. Available online: https: / cutt.ly/8jcaLyJ (accessed on 23 July 2020).

8. Muñoz, L.; Estébanez, J.L. Reflexiones para la reorganización de residencias en el contexto de la pandemia por COVID-19. Form. Médica Contin. En Atención Primaria 2020, 27, 390-397.

9. Pérez, J.; Abellán, A.; Aceituno, P.; Ramiro, D. Un Perfil de las Personas Mayores en España, 2020. Indicadores Estadísticos Básicos. Madrid, Informes Envejecimiento en red n ${ }^{\circ} 25$. Available online: https: / / cutt.ly/hjcp3pj (accessed on 21 September 2020).

10. Gálvez, A.M.P.; Romero, B.B.; Trigo, S.B.; Serrano, M.L. Personas mayores, dependencia y vulnerabilidad en la pandemia por coronavirus: Emergencia de una integración social y sanitaria. Enferm Clin. 2020. [CrossRef]

11. Instituto Nacional de Estadística. Avance de la Estadística del Padrón Continuo a 1 de enero de 2020. Available online: https:/ / www.ine.es/prensa/pad_2020_p.pdf (accessed on 13 September 2020).

12. AS. Residencias de Mayores en España: Cuántas hay y Cuántas Personas Tienen. Available online: https://cutt.ly/UjvVd3F (accessed on 23 July 2020).

13. Centro Nacional de Epidemiología (ISCIII). Vigilancia de los Excesos de Mortalidad por Todas las Causas. MoMo. Available online: https: / / cutt.ly / TjcauIE (accessed on 1 December 2020).

14. RTVE. Radiografía del Coronavirus en Residencias de Ancianos: Más de 23.700 Muertos con COVID-19 o Síntomas Compatibles. Available online: https:/ / cutt.ly /Ojcaa9c (accessed on 3 December 2020).

15. McMichael, T.M.; Currie, D.W.; Clark, S.; Pogosjans, S.; Kay, M.; Schwartz, N.G.; Lewis, J.; Baer, A.; Kawakami, V.; Lukoff, M.D.; et al. Epidemiology of Covid-19 in a long-term care facility in King County, Washington. N. Engl. J. Med. 2020, 382, 2005-2011. [CrossRef] [PubMed]

16. Blanco-Tarrio, E.; Blanco, G. Atención primaria y residencias de ancianos: A propósito de la COVID-19. SEMERGEN 2020, 46 (Suppl. 1), 26-34. [CrossRef]

17. Centro de Coordinación de Alertas y Emergencias Sanitarias (CCAES). Enfermedad por Coronavirus, COVID-19. Available online: https: / / cutt.ly / kjcamWp (accessed on 12 November 2020).

18. BOE. Real Decreto 463/2020, de 14 de Marzo, por el que se Declara el Estado de Alarma para la Gestión de la Situación de Crisis Sanitaria Ocasionada por el COVID-19. Available online: https:/ /www.boe.es/diario_boe/txt.php?id=BOE-A-2020-3692 (accessed on 12 October 2020).

19. BOE. Ley 39/2006, de 14 de Diciembre, de Promoción de la Autonomía Personal y Atención a las Personas en Situación de Dependencia. 2006. Available online: https:/ / www.boe.es/buscar/act.php?id=BOE-A-2006-21990 (accessed on 13 October 2020).

20. SAAD. Histórico. Informes Publicados. Available online: https://cutt.ly/8jcaO3R (accessed on 14 March 2020).

21. Martínez-López, J.A. El modelo híbrido de atención a las personas en situación de dependencia: Una década de cambios normativos y ajustes presupuestarios. Rev. Del Clad Reforma Y Democr. 2017, 68, 135-168. 
22. Martínez-López, J.A. Ley de Dependencia: La fragilidad de los servicios, a la necesidad de la prestación económica. Doc. De Trab. De Sociol. Apl. 2014, 34, 1-25.

23. Martínez-López, J.A.; Frutos Balibrea, L.; Solano Lucas, J.C. Los usos de las prestaciones económicas de la dependencia en el municipio de Murcia. Un estudio de Caso. Revista Española de Sociología 2017, 26, 97-113. [CrossRef]

24. Minguela, M.A.; Mayor-Rodríguez, J. Modelos de cuidado a personas en situación de dependencia en España. Un análisis desde la Gobernanza pública (2008-2019). Fund. Caser. Actas De Coord. Sociosanitaria 2019, 25, 11-29.

25. Simón, M.; Blesa, A.; Calvo, M.; Gómez, C. Estresores laborales y satisfacción en la enfermería de una unidad de críticos. Enfermería Intensiva 2005, 16, 3-14. [CrossRef]

26. Mikolajczak, M.; Gross, J.J.; Stinglhamber, F.; Norberg, A.L.; Roskam, I. Is parental burnout distinct from job burnout and depressive symptomatology? Clin. Psychol. Sci. 2020, 8, 673-689. [CrossRef]

27. Boada, J.; De Diego, R.; Agulló, T.E. El burnout y las manifestaciones psicosomáticas como consecuentes del clima organizacional y de la motivación laboral. Psicothema 2004, 16, 125-131.

28. Tremearne, R.; Calvo, F.; Alonso, J. Síndrome de Burnout en Profesionales Sanitarios. 2005. Available online: https://www.resear chgate.net/profile/Fernando_Calvo3/publication/241221960 (accessed on 20 July 2020).

29. Mingote Adán, J.C.; Pérez García, S. Estrés en la Enfermería. El Cuidado del Cuidador; Ediciones Díaz de Santos: Madrid, Spain, 2003.

30. Ortega, C.; López, F. El burnout o síndrome de estar quemado en los profesionales sanitarios: Revisión y perspectivas. Int. J. Clin. Healthy Psichol. 2004, 4, 137-160.

31. Shirom, A.; Melamed, S.; Toker, S.; Berliner, S.; Shapira, I. Burnout and health review: Current knowledge and future research directions. Int. Rev. Ind. Organ. Psychol. 2005, 20, 269-308.

32. Schonfeld, I.S.; Bianchi, R. Burnout and depression: Two entities or one? J. Clin. Psychol. 2016, 72, 22-37. [CrossRef] [PubMed]

33. Moya-Albiol, L.; Serrano, M.A.; González-Bono, E.; Rodríguez-Alarcón, G.; Salvador, A. Respuesta psicofisiológica de estrés en una jornada laboral. Psicothema 2005, 17, 205-211.

34. Schaufeli, W.B.; Leiter, M.P.; Maslach, C. Burnout: 35 years of research and practice. Career Dev. Int. 2009, 14, 204-220. [CrossRef]

35. Maslach, C.; Jackson, S.E.; Leiter, M.P. Maslach Burnout Inventory Manual; Mind Garden: Menlo Park, CA, USA, 2010.

36. Menezes de Lucena, V.A.; Fernández, B.; Hernández, L.; Ramos, F.; Contador, I. Resiliencia y el modelo Burnout-Engagement en cuidadores formales de ancianos. Psicothema 2006, 18, 791-796.

37. Maslach, C.; Jackson, S. Maslach Burnout Inventory; Consulting Psychology Press: Palo Alto, CA, USA, 1981.

38. Gil-Monte, P.R. Factorial validity of the Maslach Burnout Inventory (MBI-HSS) among Spanish professionals. Rev. Saúde Pública 2005, 39, 1-8. [CrossRef]

39. Gómez-Galán, J.; Lázaro-Pérez, C.; Martínez-López, J.Á.; Fernández-Martínez, M.M. Burnout in Spanish Security Forces during the COVID-19 Pandemic. Int. J. Environ. Res. Public Health 2020, 17, 8790. [CrossRef]

40. Méndez, I.; Secanilla, E.; Martínez, J.P.; Navarro, J. Estudio comparativo de burnout en cuidadores profesionales de personas mayores institucionalizadas con demencias y otras enfermedades. Eur. J. Investig. Health Psychol. Educ. 2015, 1, 61-70. [CrossRef]

41. Garnier, A.; López, S.; Tirado, S.; Rodriguez, J. Burnout en Médicos de Urgencias. La Búsqueda del Mes. 2001. Available online: http:/ / www.copsa.es (accessed on 2 July 2019).

42. Morales, G.; Gallego, L.M.; Rotger, D. La Incidencia y Relaciones de la Ansiedad y el Burnout en los Profesionales de Intervención en Servicios Sociales. INTERPSIQUIS. Available online: www.psiquiatría.com (accessed on 21 August 2019).

43. Guevara, C.A.; Henao, D.P.; Herrera, J.A. Síndrome de desgaste profesional en médicos internos y residentes. Hospital Universitario del Valle, Cali. Rev. Colomb. Médica 2004, 35, 173-178.

44. Ordenes, N. Prevalencia de Burnout en trabajadores del hospital Roberto del Río. Rev. Chil. De Pediatría 2004, 75, 449-454. [CrossRef]

45. Chen, Q.; Liang, M.; Li, Y.; Guo, J.; Fei, D.; Wang, L.; He, L.; Sheng, C.; Cai, Y.; Li, X.; et al. Mental healthcare for medical staff in China during the COVID19 outbreak. Lancet Psychiatry 2020, 7, e15-e16. [CrossRef]

46. Mapfre. Evolución del Mercado de Trabajo: Profesiones en Auge. Available online: https://cutt.ly/Fjcs7Qd (accessed on 3 September 2019).

47. Atance, J.C. Aspectos epidemiológicos del síndrome de Burnout en personal sanitario. Rev. Esp. Salud Publica. 1997, 71, 293-303. [CrossRef]

48. Failde, J. Personalidad resistente, burnout, estado de salud y calidad de vida relacionada con la salud en profesionales sociosanitarios de centros gerontológicos. Salud I Cienc. 2019, 19, 599-606.

49. Megías-Lizancos, F.; Castro-Molina, F.J. Manejo del Estrés en Profesionales Sanitarios; DAE Editorial: Madrid, Spain, 2018.

50. Adams, T.L. Gender and feminization in healthcare professions. Sociol. Compass 2010, 4, 454-465. [CrossRef]

51. Martínez-López, J.A.; Frutos Balibrea, L.; Solano Lucas, J.C. El Trabajo de Cuidados en el Sistema de la Dependencia; Tirant lo Blanch: Madrid, Spain, 2020.

52. Gómez, A.M.; Navarro, J.R. Feminización, cuidados y generación soporte: Cambios en las estrategias de las atenciones a mayores dependientes en el medio rural. Prism. Soc. Rev. De Investig. Soc. 2018, 21, 219-242.

53. Martínez-López, J.A.; Lázaro-Pérez, C.; Gómez-Galán, J.; Raducea, M. Aproximación a los cuidados de larga duración durante el pico de la COVID-19 en la Región de Murcia. Prism. Soc. Rev. De Investig. Soc. 2021, 32, 128-146.

54. Santos Mayor, M. El Burnout en las Residencias Geriátricas: El caso del centro Txara II de Gipuzkoa. Ph.D. Thesis, Universidad Nacional de Educación a Distancia, Madrid, Spain, 2017. 
55. Tobie-Gutiérrez, W.A.; Nava-López, J.A. Burnout, su impacto en la residencia médica y en la atención de los pacientes. Rev. Mex. De Anestesiol. 2012, 35, 233-237.

56. Panneton, P.E.; Wesolowski, E.F. Current and future needs in geriatric education. Public Health Rep. 1979, 94, 73-79. [PubMed]

57. Kappelman, M.M.; Bartnick, L.A.; Cahn, B.; Rapoport, M.I. A nontraditional geriatric teaching model: Interprofessional service/education sites. J. Med. Educ. 1981, 56, 467-477. [CrossRef] [PubMed]

58. Bardach, S.H.; Rowles, G.D. Geriatric education in the health professions: Are we making progress? Gerontologist 2012, 52, 607-618. [CrossRef]

59. Williams, J.; Nocera, M.; Casteel, C. The effectiveness of disaster training for healthcare workers: A systematic review. Ann. Emerg. Med. 2008, 52, 211-222. [CrossRef]

60. Monteiro, R.; Rodriguez, C.J.; Moreira, P.; Leite, M. Psychological effects caused by the COVID-19 pandemic in health professionals: A systematic review with meta-analysis. Prog. Neuro-Psychopharmacol. Biol. Psychiatry 2021, 10, 110062.

61. Shojaei, S.F.; Masoumi, R. The importance of mental health training for psychologists in COVID-19 outbreak. Middle East. J. Rehabil. Health Stud. 2020, 7, e102846. [CrossRef]

62. Lázaro-Pérez, C.; Martínez-López, J.A.; Gómez-Galán, J.; López-Meneses, E. Anxiety about the risk of death of their patients in health professionals in Spain: Analysis at the peak of the COVID-19 pandemic. Int. J. Environ. Res. Public Health 2020, 17, 5938. [CrossRef] [PubMed]

63. Ho, C.S.; Chee, C.; Ho, R. Mental health strategies to combat the psychological impact of coronavirus disease 2019 (COVID-19) beyond paranoia and panic. Ann. Acad. Med. Singap. 2020, 49, 155-160. [CrossRef] [PubMed]

64. Prak, S.; González, N. Por qué apostar por un entorno laboral sostenible: El ejemplo de Impact Hub Madrid. Obs. De Recur. Hum. Y Relac. Labor. 2019, 147, 59-63.

65. Guerrero, M. En busca de un Entorno Laboral Sostenible. Available online: https://cutt.ly/sjcfhIw (accessed on 3 January 2021).

66. Aleksić, A.; Načinović Braje, I.; Rašić Jelavić, S. Creating sustainable work environments by developing cultures that diminish deviance. Sustainability 2019, 11, 7031. [CrossRef]

67. Pinheiro, M.; Ivandic, I.; Razzouk, D. The economic impact of mental disorders and mental health problems in the workplace. In Mental Health Economics; Razzouk, D., Ed.; Springer: Cham, Switzerland, 2017; pp. 415-430.

68. Rasool, S.F.; Maqbool, R.; Samma, M.; Zhao, Y.; Anjum, A. Positioning depression as a critical factor in creating a toxic workplace environment for diminishing worker productivity. Sustainability 2019, 11, 2589. [CrossRef]

69. Rasool, S.F.; Wang, M.; Zhang, Y.; Samma, M. Sustainable work performance: The roles of workplace violence and occupational stress. Int. J. Environ. Res. Public Health 2020, 17, 912. [CrossRef]

70. Walpole, S.C.; Barna, S.; Richardson, J.; Rother, H.A. Sustainable healthcare education: Integrating planetary health into clinical education. Lancet Planet. Health 2019, 3, e6-e7. [CrossRef]

71. Huss, N.; Ikiugu, M.N.; Hackett, F.; Sheffield, P.E.; Palipane, N.; Groome, J. Education for sustainable healthcare: From learning to professional practice. Med. Teach. 2020, 42, 1097-1101. [CrossRef] [PubMed]

72. Gómez-Galán, J. Nuevos estilos de enseñanza en la era de la convergencia tecno-mediática: Hacia una educación holística e integral. Int. J. Educ. Res. Innov. 2017, 8, 60-78.

73. Dossey, B.M.; Rosa, W.E.; Beck, D.M. Nursing and the sustainable development goals: From Nightingale to now. Am. J. Nurs. 2019, 119, 44-49. [CrossRef] 